\title{
Analysis of Groundwater Quality using Mamdani Fuzzy Inference System (MFIS) in Yazd Province, Iran
}

\author{
A. Saberi Nasr \\ P.H.D. student in hydrogeology \\ Faculty of Science, geology \\ group, Kharazmi University, \\ Tehran, Iran
}

\author{
M. Rezaei \\ Assistant Professor of \\ hydrogeology, Faculty of \\ Science, geology group, \\ Kharazmi University \\ Tehran, Iran
}

\author{
M. Dashti Barmaki \\ P.H.D. student in hydrogeology \\ Faculty of Science, geology \\ group, Kharazmi University, \\ Tehran, Iran
}

\begin{abstract}
Precise classification and identification of groundwater quality is an essential task for meeting the goals of environmental management. Traditional classification methods of the water quality parameters use crisp set with prescribed limits of various organization. One of the decision making problems about water quality using methods is facing various uncertainties. Recent years have proven fuzzy-logicbased methods capability controlling uncertainties in different environmental problems. The present study utilized a newly devised Mamdani fuzzy inference system to assess groundwater quality in Yazd province. This method made use of 10 measured chemical parameters in 60 samples of groundwater. The samples were collected from wells, springs and kanats. The results showed that 20 groundwater samples were in the "Desirable" class with a certainty level of 32.29$100 \%$, and 20 samples were in the "Acceptable" group with a certainty level of $37.07-92 \%$, and 20 samples were in the "Non-acceptable" category with a certainty level of 43.33$88.78 \%$ for potable purposes.
\end{abstract}

\section{Keywords}

groundwater quality, crisp set, Mamdani fuzzy inference, certainty level, potable purposes.

\section{INTRODUCTION}

The environmental protection and water quality management of water resources is one of the most important issues in public policies throughout the world. More than that government is concerned about the quality of their environmental resources because of the complexity in water quality data sets [1]. Therefore a variety of methods for evaluating water quality are discussed in many literatures such as Fuzzy Synthetic Evaluation [2; 3; 4], Artificial Neural Network (ANN) [5; 6], Fuzzy Inference Systems (FIS) $[1 ; 7$; 8], Grey Relation Method (GRM) [9], Water Quality Index (WQI) $[10 ; 11 ; 12 ; 13]$, Single Index Evaluation (SIE), The Simplified Water Quality Index (ISQA) and so on.

One of the most popular and commonly used methods during last few decades was Water Quality Index (WQI) using Delphi technique; National Sanitation Foundation (NSF) developed this methodology as a tool in formal assessment procedure $[2 ; 8 ; 14]$. Comparing determined limits of different indicators of water quality, WQI assesses water quality by adding the multiplication of the respective weight factor by an appropriated quality-value for each parameter. However, WQI, ISQA, and other similar indices exhibit a number of weak points, which enable the assignation of a quality value using a limited number of parameters. Most indices do not consider toxic pollutants such as heavy metals, hydrocarbons, or pesticides. In turn, some parameters in the index equation can influence dramatically the final score without valid justification, while their formulations are rather elementary, and the number of variables involved is too limited. However, the most critical deficiency of these indices is the lack of dealing with uncertainty and subjectivity present in this complex environmental problem [8].

Along with the limitations of these methods, conventional water quality regulation proposed by various regulatory bodies like Word Health Organization (WHO), Institute of Standards and Industrial Research of Iran (ISIRI) contain quality classes which use crisp sets, and the limits between different classes have inherent imprecision [15].Furthermore, to monitor water quality and to make qualitative and quantitative decisions based on real data has become a challenge for environmental engineers and hydrogeologist over all stages of the process, from data collection, storage and processing up to analysis and interpretation of the results. Uncertainties accumulate along this chain $[2 ; 3 ; 16]$.

Sii et al [17] and Garg [18] have discussed the uncertainties involved in water quality using fuzzy membership with value ranging from 0 to 1 to form an applicable fuzzy set instead of the conventional scale of 0 to 100 in WQI methodology. This issue has been widely discussed in various sources [see 19; 20; 21]. During recent years, the Mamdani FIS, using fuzzy set mathematical methodology, has been easily accepted by both researchers and decision makers due to its ability to handle the uncertainties in Geoscience, and water resources. But regarding the fact that several studies using this type of system [i.e., $8 ; 22 ; 23 ; 24 ; 25 ; 26 ; 27 ; 28$ ] have been published related to various branches of Geosciences and water resources, a Mamdani FIS has been applied for a limited number of groundwater quality assessments to date.

In this study, the aim is to develop a method based on fuzzy logic instead of the conventional crisp classification method to remove the ambiguities mentioned above. In the method, membership functions of the quality parameters and fuzzy rule bases were defined and then fuzzy logic toolbox of MATLAB package was used.

\section{MATERIAL AND METHODS}

\subsection{Fuzzy systems}

Zadeh [29] founded fuzzy logic which is very useful in modeling complex and imprecise systems. Fuzzy logic provides basic for implementing expert supervised rules which is the main goal in the field of knowledge-based systems. By this way, the human expertise plays the most significant role in the engineering process. The other important reason for applying fuzzy logic is to be 
overwhelmed by available vague information of the practitioners [30]. Fuzzy logic (FL) provides a simple way to arrive at a definite conclusion based upon vague, ambiguous, imprecise, noisy, or missing input information. Fuzzy logic starts with the concept of a fuzzy set. A fuzzy set describes the relationship between an uncertain quantity $\mathrm{x}$ and $\mathrm{a}$ membership function $\mu$, which ranges between 0 and 1 . A fuzzy set is an extension of the traditional (or crisp) set theory (in which $\mathrm{x}$ is either a member of set $\mathrm{A}$ or not) in that an $\mathrm{x}$ can be a member of set A with a certain degree of membership $\mu$ [31]. Mathematically, the fuzzy set can be represented as follows [8; 32]:

$$
A=\left\{x, \mu_{A}(x) \mid x \in U\right\}
$$

Where $\mu_{\mathrm{A}}(\mathrm{x})$ is called the MF of $\mathrm{x}$ in $\mathrm{A}$ and $\mathrm{U}$ is a universe of discourse set.

\subsection{Fuzzy Inference System (FIS)}

Fuzzy inference is defined as the process of mapping a set of input data sets into a set of output data, using an approach based on fuzzy logic and falls under the category of black box models [33]. A FIS tries to formalize the reasoning process of human language by means of fuzzy logic (that is, by building fuzzy IF-THEN rules). A FIS is normally composed of four basic elements including fuzzification, fuzzy rule base, fuzzy inference engine and defuzzification. This particular type of systems is generally suitable for resolving vagueness associated problems by implementing fuzzy algorithm [30]. A graphic presentation of a fuzzy inference system is shown in Fig 1.

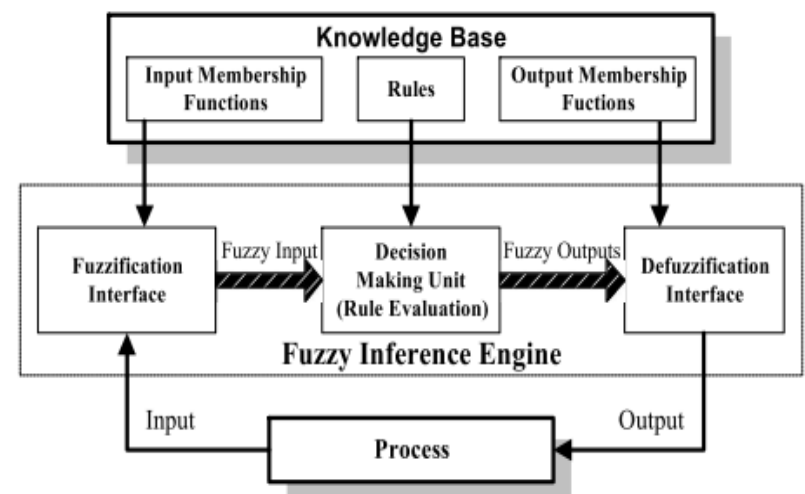

Fig 1: General structure of fuzzy inference system

\subsection{Fuzzification}

As in all applications input and output of fuzzy system are real numbers, we should mediate between fuzzy inference engine and the environment. These mediators are just fuzzifier and defuzzifier. In the fuzzification unit, input values are considered as fuzzy singletons and membership grades of all fuzzy propositions in the rule antecedents are evaluated. Fuzzification means using the membership functions of linguistic variables to compute each term's degree of validity at a specific point of the process. When a fuzzy rule activates, it fires to a certain degree of depending on the belief level in each antecedents are evaluated in the premise of the rule.

The fuzzification is carried out through membership functions. The membership functions are the characteristic function of a fuzzy set, which assigns to each element in a universal set a value between 0 and 1 . The shape of a membership function depends on the application and can be trapezoidal, bell-shaped, triangular, or Gaussian, etc. The most commonly used is the liner type, trapezoidal and triangular [4]. A trapezoidal MF is specified by four parameters a, b, c, d, with $\mathrm{a}<\mathrm{b}<\mathrm{c} \leq \mathrm{d}$, and a triangular MF is specified by three parameters $\mathrm{a}, \mathrm{b}$, c with $\mathrm{a}<\mathrm{b}<\mathrm{c}$ as following [16; 32]:

$$
\begin{gathered}
\operatorname{trapmf}(x ; a, b, c, d)=\left\{\begin{array}{cc}
0, & x \leq a \\
x-a / b-a & a \leq x \leq b \\
1, & b \leq x \leq c \\
d-x / d-c, & c \leq x \leq d \\
0, & d \leq x
\end{array}\right. \\
\operatorname{trimf}(x ; a, b, c)=\left\{\begin{array}{cc}
0, & x<a \\
x-a / b-a, & a \leq x \leq b \\
c-x / c-b, & b \leq x \leq c \\
0, & c<x
\end{array}\right.
\end{gathered}
$$

\subsection{Fuzzy rule base}

In knowledge-based systems, the relation between input and output linguistic variables is expressed in terms of a set of fuzzy if-then rules (conditional propositional forms). From these rules and any fact describing actual states of input variables, the actual states of output variables are derived by an appropriate compositional rule of inference. In fuzzy inference system (or fuzzy- rules- base system), every fuzzy rule has two parts $[33 ; 34]$ :

1- $\quad$ Antecedent part (premise), expressed by: IF...

2- Consequent part, expressed by: THEN....

In a fuzzy model, each rule is shown as a relation that is calculated through following equation [35]:

$$
\mu_{R i}(x, y)=I\left(\mu_{A i}(x), \mu_{B i}(y)\right), \quad i=1,2, \ldots, n
$$

Where $\mu_{\mathrm{Ri}}(\mathrm{x}, \mathrm{y})$ is the relation's membership degree of rule " $i$ " according to " $\mathrm{x}$ " and " $\mathrm{y}$ " inputs, $\mu_{\mathrm{Ai}}(\mathrm{x})$ and $\mu_{\mathrm{Bi}}(\mathrm{y})$ are the membership degrees of " $x$ " and " $y$ " inputs respectively, " $I$ " denotes the "and" or "or" operator and " $n$ " is the number of rules.

\subsection{Fuzzy inference engine}

The inference system or the decision-making unit performs the inference operations on the rules. It handles the way in which the rules are combined [7]. In other words, Using IfThen type, fuzzy rules convert the fuzzy input to the fuzzy output (Fig 2).

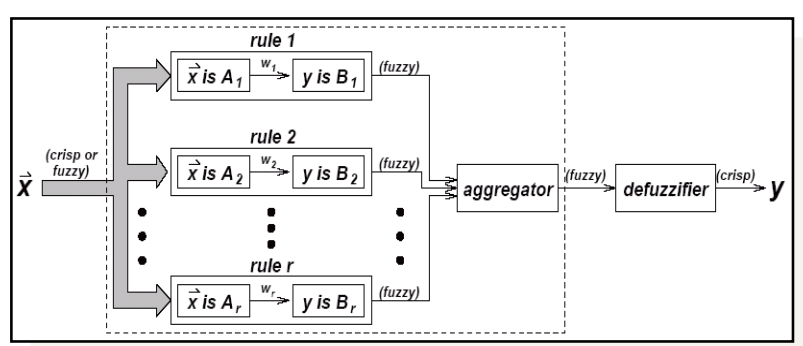

Fig 2: The schematic of the fuzzy inference engine

\subsection{Defuzzification}

Defuzzification works opposite to the fuzzification in operation. It consists in transforming the fuzzy output into a final crisp output which can be used in no-fuzzy contexts. There are several commonly used operators for defuzzification, including centroid of area (COA) method that is often referred to as the center-of-gravity method (centroid- 
COG), smallest of the maximums, max or mean-max membership principles and the weighted-average method. However, the most commonly used operator is the center of gravity $[8 ; 14 ; 30]$. In this method the fuzzy scheme is converted to a crisp value using the following formula $[8 ; 14$; 26; 30]:

$$
Z_{C O A}=\int_{z} \mu_{A}(z) z d z / \int_{z} \mu_{A}(z) d z
$$

Where $\mathrm{Z}_{\mathrm{COA}}$ is the crisp value for the " $\mathrm{z}$ " output and $\mu_{\mathrm{A}}(\mathrm{z})$ is the aggregated output membership function.

\subsection{Mamdani fuzzy model}

Several types of FIS have been recommended by researchers, upon the differences between the specification of the consequent part and the defuzzification methods [24;36]. Two commonly used inference systems are Mamdani fuzzy model [37] and Takagi-Sugeno [38] fuzzy model. Mamdani fuzzy model is based on the collections of IF-THEN rules with both fuzzy antecedent and consequent parameters $[7 ; 39$; 40]. It is also called a linguistic model because both the antecedent and the consequent are fuzzy propositions. Sugeno fuzzy model was proposed by Takagi and Sugeno. This model is built with if-then rules that have fuzzy antecedent and functional consequent [7].

Mamdani fuzzy model due to its popularity and easily application is the most commonly seen fuzzy methodology. Mamdani model can be built by using linguistic relationships and observed data. The Mamdani-based fuzzy models use excessive number of rules for system modeling. Let $X$ be input (regression) matrix and $\mathrm{g}$ an output vector defined as follows:

$$
\begin{aligned}
& X=\left[x_{1}, \ldots, x_{2}\right]^{T}=\left[\begin{array}{cc}
x_{11} & x_{12} \\
x_{21} & x_{22} \\
\vdots & \vdots \\
x_{n 1} & x_{n 2}
\end{array}\right] \\
& g=\left[g_{1}, \ldots, g_{n}\right]
\end{aligned}
$$

where upper script $\mathrm{T}$ denotes the transpose. The general ifthen structure of the Mamdani algorithm is given as:

$$
R_{i} \text { :if } x \text { is } A_{i} \text { and ...then } y \text { is } B_{i}(\text { for } i=1,2, \ldots, k)
$$

Where $k$ is the numbers of rules; $R_{i}$ is the rule number, $A_{i}$ and $B_{i}$ are the fuzzy sets, $x$ is the antecedent variable representing the input in the fuzzy system, and $\mathrm{y}$ is the consequent variable related to the output of the fuzzy system [26; 39]. Although many methods for the composition of fuzzy relations (e.g., min-max, $\max -\max , \min -\min , \max -$ $\min$, etc.) are available in the literature, the $\max -\min$ and max-product methods are the two most commonly used techniques [26]. Max-min composition is represented by Eq. (7). Also a graphic illustration of a two-rule max-min composition Mamdani FIS model is shown in Fig 3.

$$
\mu_{C_{K}}(Z)=\max \left[\min \left[\mu_{A_{K}}(\operatorname{input}(x)), \mu_{B_{K}}(\operatorname{input}(y))\right]\right]
$$$$
K=1,2, \ldots, r
$$

where $\mu_{C_{K}}, \mu_{A_{K}}$ and $\mu_{B_{K}}$ are the membership functions of output " $\mathrm{z}$ " for rule " $\mathrm{k}$ ", input " $\mathrm{x}$ " and input " $\mathrm{y}$ ", respectively.

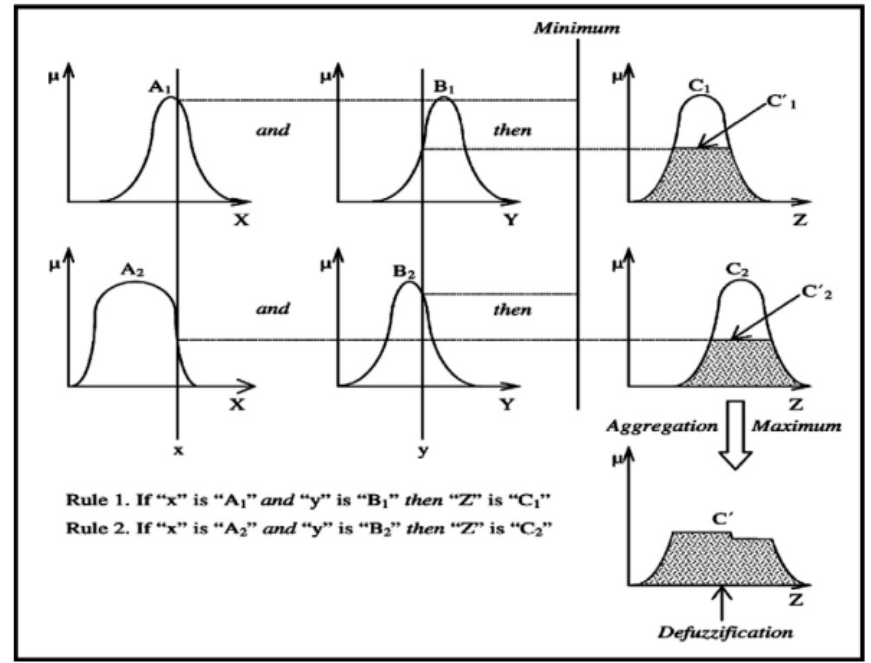

Fig 3: The Mamdani FIS

\section{STUDY AREA AND DATA}

Yazd province with an area of $131575 \mathrm{Km}^{2}$ located in the center of Iran is selected for this study (between $29^{\circ} 52^{\prime}$ and $33^{\circ} 27^{\prime}$ North latitude and $52^{\circ} 55^{\prime}$ and $56^{\circ} 37^{\prime}$ East longitude), where the average temperature is significantly high whereas the rainfall is relatively low.The average annual rainfall of the study area has been reported as $108 \mathrm{~mm}$. In this area, exploitation of aquifers is done through wells, springs and kanats. Excessive withdrawal of groundwater has decreased the water level and water quality so that some sources of potable water are out of the admissible limit of existing standards (i.e. WHO). So, it seems imperative to pay attention to water quality for its management.

In this study, 60 groundwater samples were selected out of potable resources of 55 rural areas. The samples were collected from wells, springs and kanats. Implementation and investigation of chemical and physical analysis on the samples showed that the proportion of some of the parameters influencing potability as Coliform, Manganese $\left(\mathrm{Mn}^{2+}\right)$, ferrous ion $\left(\mathrm{Fe}^{2+}\right)$ was much less expected than the current standards. Therefore, 10 parameters, including: $\mathrm{PH}$, Total Hardness (TH), Total Dissolved Solid (TDS), Total Alkalinity (TA), Calcium $\left(\mathrm{Ca}^{2+}\right)$, Magnesium $\left(\mathrm{Mg}^{2+}\right)$, Sulphate $\left(\mathrm{SO}_{4}^{2-}\right)$, Chloride $\left(\mathrm{Cl}^{-}\right)$, Nitrate $\left(\mathrm{NO}_{3}{ }^{-}\right)$and Fluoride $\left(\mathrm{F}^{-}\right)$were used to assess the groundwater quality for potable purposes using Mamdani Fuzzy Inference System (MFIS) model.

To show an overview of the qualitative data, the statistical parameters such as minimum value (Min), maximum value (Max), mean and standard deviation (S.D.) for each parameter are calculated and given in Table 1.

Table 1. summary of basic statistical parameter

\begin{tabular}{|l|l|l|l|l|}
\hline \multirow{2}{*}{ Parameter } & \multicolumn{4}{|l|}{ Statistical parameters } \\
\cline { 2 - 5 } & Mean & Min & Max & S.D. \\
\hline $\mathrm{PH}$ & 7.48 & 5.84 & 8.21 & 0.48 \\
\hline $\mathrm{TA}$ & 218.38 & 80 & 730 & 109.73 \\
\hline $\mathrm{TH}$ & 476.63 & 100 & 1920 & 405.4 \\
\hline $\mathrm{TDS}$ & 1222.2 & 153.6 & 5459.2 & 1096.9 \\
\hline $\mathrm{Ca}^{2+}$ & 116.09 & 24 & 446.4 & 87.98 \\
\hline $\mathrm{Mg}^{2+}$ & 46.86 & 0.97 & 303.26 & 6.81 \\
\hline $\mathrm{Cl}^{-}$ & 269.93 & 12 & 1619.9 & 324 \\
\hline $\mathrm{SO}_{4}{ }^{2-}$ & 211.17 & 8 & 1350 & 27.43 \\
\hline $\mathrm{NO}_{3}{ }^{-}$ & 24.49 & 1.3 & 150 & 28.48 \\
\hline Fluoride & 1.357 & 0.02 & 6.6 & 1.74 \\
\hline
\end{tabular}




\section{RESULT AND DISCUSSION}

In the deterministic method of water quality assessment, 10 qualitative parameters are compared with standard prescribed limits. Then, the results attributed to each parameter are described as "desirable", "acceptable" and "not acceptable". But in MFIS method, According to the expert perception, 10 qualitative parameters of groundwater were classified into three groups. TDS, TA, $\mathrm{Cl}^{-}$and $\mathrm{SO}_{4}{ }^{2-}$ Parameters were categorized in the first, $\mathrm{PH}, \mathrm{TH}, \mathrm{Ca}^{2+}$ and $\mathrm{Mg}^{2+}$ in the second and Nitrate $\left(\mathrm{NO}_{3}^{-}\right)$and Fluoride $\left(\mathrm{F}^{-}\right)$in the third group.

Fluoride and Nitrate are two important factors determining water quality with regard to potability. Fluoride shortage in potable water results in dental caries (tooth decay) while its abundance leads to skeletal fluorosis and Osteochondroma [41]. Studies already link fluoride to cancer, genetic defects, IQ deficits, thyroid dysfunction, kidney, tooth and bone damage $[42 ; 43 ; 44]$. The minimum and maximum Fluoride concentration in water depends on temperature and geographical region [45] so that it is reduced either by an increase in temperature or in coastal areas. Generally speaking, proper Fluoride concentration in water is estimated between 0.5 to $1.5 \mathrm{mg} / \mathrm{L}$ [46]. Moreover, Nitrate causes undesirable effects, severe intoxication and methemoglobinemia (blue baby syndrome) or even death among infants $[47 ; 48]$. Therefore, Taking into account the importance of Nitrate $\left(\mathrm{NO}_{3}{ }^{-}\right)$and Fluoride $\left(\mathrm{F}^{-}\right)$to determine the quality of water potability, these two parameters individually along with the output results from the first and second group formed the third group. Fuzzy membership functions constructed for all the 10 parameters are either triangular or trapezoidal on the basis of expert perception and prescribed limits by Word Health Organization [49] and Institute of Standards and Industrial Research of Iran [50] (Table 2) for MFIS model to classify water quality. These membership functions are shown in Fig 4. As can be seen from this figure, the fuzzy sets are classified into "desirable", "acceptable" and "not acceptable".

Table 2. The limits prescribed by Word Health Organization [49] and Institute of Standards and Industrial Research of Iran [50] for the studied parameters

\begin{tabular}{|l|l|l|l|l|}
\hline \multirow{2}{*}{ parameter } & \multicolumn{3}{|l|}{ WHO (2006) } & IRISI \\
\cline { 2 - 5 } & Desirable & Acceptable & Desirable & Acceptable \\
\hline $\mathrm{PH}$ & $7-8.5$ & $6.5-9.2$ & $7-8.5$ & $6.5-9.2$ \\
\hline TA & 200 & 600 & - & - \\
\hline TH & 300 & 600 & 150 & 500 \\
\hline $\mathrm{TDS}$ & 500 & 1500 & 500 & 1500 \\
\hline $\mathrm{Ca}^{2+}$ & 75 & 200 & 75 & 200 \\
\hline $\mathrm{Mg}^{2+}$ & 50 & 100 & 50 & 150 \\
\hline $\mathrm{Cl}^{-}$ & 200 & 1000 & 200 & 600 \\
\hline $\mathrm{SO}_{4}{ }^{2-}$ & 200 & 400 & 200 & 400 \\
\hline $\mathrm{NO}_{3}{ }^{-}$ & 20 & Not>100 & 20 & 45 \\
\hline Fluoride & 1 & 1.5 & - & - \\
\hline
\end{tabular}

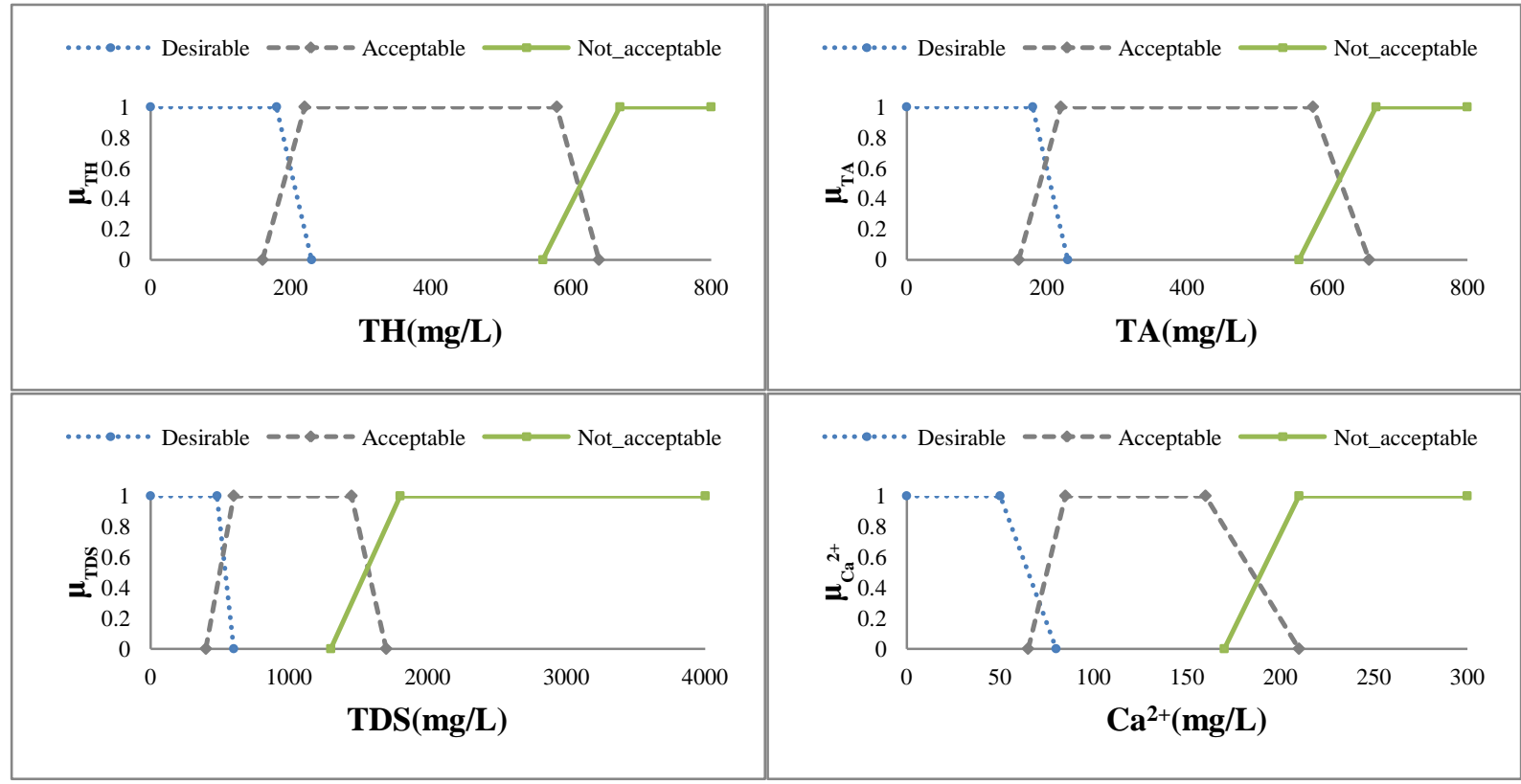

Fig 4: Membership functions defined for water quality parameters used in the study 


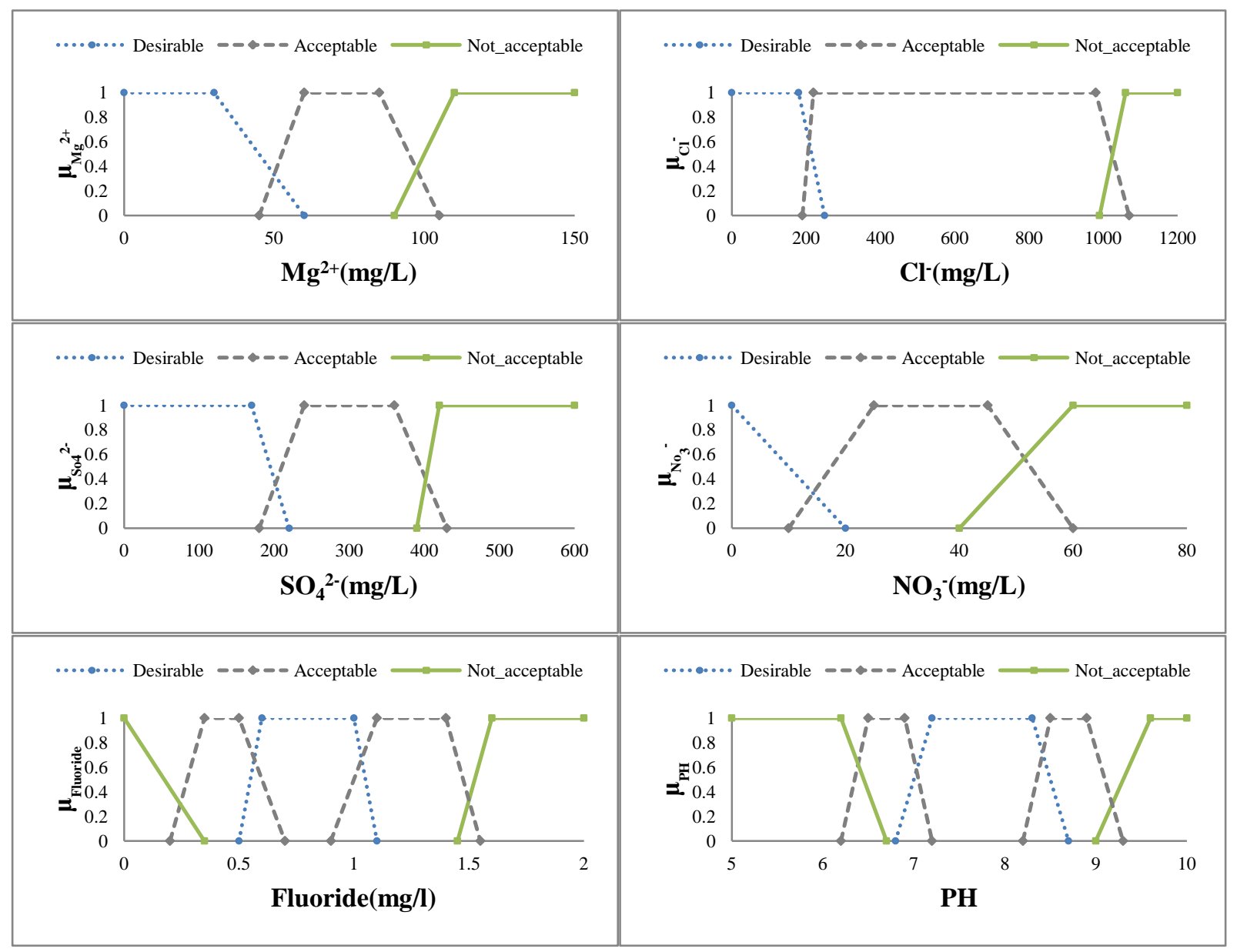

Fig 4: Continued

Table 3. Some sample rules out of 351 rules designed on the expert knowledge basis for the water quality parameters

\begin{tabular}{|c|c|c|}
\hline \multicolumn{3}{|c|}{ Group 1} \\
\hline Rule no. & Antecedent part & Consequent part \\
\hline $\mathrm{R}_{1}$ & IF TDS=Desirable AND TA=Desirable AND Cl=Desirable AND $\mathrm{SO}_{4}{ }^{2-}=$ Desirable & THEN G ${ }_{1}=$ Desirable \\
\hline $\mathrm{R}_{2}$ & IF TDS $=$ Desirable AND TA $=$ Desirable AND $\mathrm{Cl}^{-}=$Desirable $\mathrm{AND} \mathrm{SO}_{4}{ }^{2-}=$ Acceptable & THEN G $_{1}=$ Desirable \\
\hline $\mathrm{R}_{3}$ & IF TDS $=$ Desirable AND TA $=$ Desirable AND Cl ${ }^{-}=$Desirable AND SO $_{4}{ }^{2-}=$ Not $\_$acceptable & THEN $\mathrm{G}_{1}=$ Desirable \\
\hline $\mathrm{R}_{4}$ & IF TDS $=$ Desirable AND TA $=$ Desirable $\mathrm{AND} \mathrm{Cl}^{-}=$Acceptable AND SO $_{4}{ }^{2-}=$ Acceptable & THEN G ${ }_{1}=$ Desirable \\
\hline $\mathrm{R}_{5}$ & IF TDS $=$ Acceptable AND TA $=$ Acceptable AND Cl$^{-}=$Acceptable AND SO $_{4}{ }^{2-}=$ Acceptable & THEN G ${ }_{1}=$ Acceptable \\
\hline $\mathrm{R}_{6}$ & IF TDS $=$ Acceptable AND TA $=$ Acceptable $\mathrm{AND} \mathrm{Cl}^{-}=$Acceptable $\mathrm{AND} \mathrm{SO}_{4}{ }^{2-}=$ Desirable & THEN G ${ }_{1}=$ Acceptable \\
\hline $\mathrm{R}_{7}$ & IF TDS $=$ Acceptable AND TA $=$ Acceptable $\mathrm{AND} \mathrm{Cl}^{-}=\mathrm{Not}_{-}$Acceptable $\mathrm{AND} \mathrm{SO}_{4}{ }^{2-}=$ Acceptable & THEN G ${ }_{1}=$ Acceptable \\
\hline $\mathrm{R}_{8}$ & IF TDS $=$ Acceptable AND TA $=$ Desirable AND Cl ${ }^{-}=$Not_Acceptable AND SO$_{4}{ }^{2-}=$ Not_Acceptable & THEN G ${ }_{1}=$ Not_Acceptable \\
\hline $\mathrm{R}_{9}$ & IF TDS $=$ Acceptable AND TA $=$ Acceptable AND Cl ${ }^{-}=$Not_Acceptable AND SO $_{4}{ }^{2-}=$ Not_Acceptable & THEN G $_{1}=$ Not_Acceptable \\
\hline $\mathrm{R}_{10}$ & IF TDS $=$ Not_Acceptable AND TA $=$ Desirable AND Cl ${ }^{-}=$Not_Acceptable $\mathrm{AND} \mathrm{SO}_{4}{ }^{2-}=$ Desirable & THEN G ${ }_{1}=$ Not_Acceptable \\
\hline \multicolumn{3}{|c|}{$\begin{array}{ll} & \text { Group 2 } \\
\end{array}$} \\
\hline Rule no. & Antecedent part & Consequent part \\
\hline $\mathrm{R}_{1}$ & IF PH $=$ Desirable AND TH $=$ Desirable AND $\mathrm{Ca}^{2+}=$ Desirable AND $\mathrm{Mg}^{2+}=$ Desirable & THEN G $\mathrm{G}_{2}=$ Desirable \\
\hline $\mathrm{R}_{2}$ & IF PH $=$ Desirable AND TH $=$ Desirable AND Ca ${ }^{2+}=$ Acceptable AND $\mathrm{Mg}^{2+}=$ Acceptable & THEN G ${ }_{2}=$ Desirable \\
\hline $\mathrm{R}_{3}$ & IF PH $=$ Desirable AND TH $=$ Desirable AND $\mathrm{Ca}^{2+}=$ Acceptable AND $\mathrm{Mg}^{2+}=$ Not_Acceptable & THEN G ${ }_{2}=$ Desirable \\
\hline $\mathrm{R}_{4}$ & IF PH $=$ Acceptable AND TH $=$ Acceptable AND $\mathrm{Ca}^{2+}=$ Acceptable AND $\mathrm{Mg}^{2+}=$ Acceptable & THEN G ${ }_{2}=$ Acceptable \\
\hline $\mathrm{R}_{5}$ & IF PH $=$ Acceptable AND TH $=$ Acceptable AND Ca ${ }^{2+}=$ Acceptable AND $\mathrm{Mg}^{2+}=$ Desirable & THEN $\mathrm{G}_{2}=$ Acceptable \\
\hline $\mathrm{R}_{6}$ & IF PH $=$ Desirable AND TH $=$ Acceptable AND $\mathrm{Ca}^{2+}=$ Acceptable AND $\mathrm{Mg}^{2+}=$ Not_Acceptable & THEN G $\mathrm{G}_{2}=$ Acceptable \\
\hline $\mathrm{R}_{7}$ & IF PH $=$ Not_Acceptable AND TH $=$ Acceptable AND $\mathrm{Ca}^{2+}=$ Acceptable AND Mg ${ }^{2+}=$ Desirable & THEN G $_{2}=$ Not_Acceptable \\
\hline $\mathrm{R}_{8}$ & IF PH $=$ Not_Acceptable AND TH $=$ Not_Acceptable AND Ca ${ }^{2+}=$ Acceptable AND $\mathrm{Mg}^{2+}=$ Desirable & THEN G ${ }_{2}=$ Not_Acceptable \\
\hline $\mathrm{R}_{9}$ & IF PH $=$ Acceptable AND TH = Acceptable AND Ca ${ }^{2+}=$ Not_Acceptable AND Mg ${ }^{2+}=$ Not_Acceptable & THEN G $_{2}=$ Not_Acceptable \\
\hline $\mathrm{R}_{10}$ & IF PH $=$ Desirable AND TH $=$ Not_Acceptable AND Ca ${ }^{2+}=$ Not_Acceptable AND $\mathrm{Mg}^{2+}=$ Not_Acceptable & THEN G $_{2}=$ Not_Acceptable \\
\hline \multicolumn{3}{|c|}{ Group 3 } \\
\hline Rule no. & Antecedent part & Consequent part \\
\hline $\mathrm{R}_{1}$ & $\mathrm{IF} \mathrm{G}_{1}=$ Desirable AND G A $_{2}=$ Desirable AND NO ${ }^{-}=$Desirable AND F ${ }^{-}=$Desirable & THEN WQ = Desirable \\
\hline $\mathrm{R}_{2}$ & $\mathrm{IF} \mathrm{G}_{1}=$ Acceptable AND G ${ }_{2}=$ Desirable AND NO $_{3}{ }^{-}=$Desirable AND F $=$Acceptable & THEN WQ = Desirable \\
\hline $\mathrm{R}_{3}$ & $\mathrm{IF} \mathrm{G}_{1}=$ Not_Acceptable AND G ${ }_{2}=$ Desirable AND NO $_{3}{ }^{-}=$Desirable AND F $=$Desirable & THEN WQ = Desirable \\
\hline $\mathrm{R}_{4}$ & IF G $_{1}=$ Not_Acceptable AND G ${ }_{2}=$ Desirable AND NO ${ }_{3}^{-}=$Acceptable AND F ${ }^{-}=$Desirable & THEN WQ = Acceptable \\
\hline $\mathrm{R}_{5}$ & $\mathrm{IF} \mathrm{G}_{1}=$ Not_Acceptable AND G ${ }_{2}=$ Acceptable AND NO ${ }_{3}^{-}=$Acceptable AND F $=$Acceptable & THEN WQ = Acceptable \\
\hline $\mathrm{R}_{6}$ & IF G $_{1}=$ Acceptable AND G ${ }_{2}=$ Acceptable AND NO $_{3}{ }^{-}=$Acceptable AND F ${ }^{-}=$Acceptable & THEN WQ = Acceptable \\
\hline $\mathrm{R}_{7}$ & $\mathrm{IF} \mathrm{G}_{1}=$ Acceptable AND G ${ }_{2}=$ Acceptable AND NO ${ }_{3}^{-}=$Not_Acceptable AND F ${ }^{-}=$Acceptable & THEN WQ = Not_Acceptable \\
\hline $\mathrm{R}_{8}$ & $\mathrm{IF} \mathrm{G}_{1}=$ Desirable AND G ${ }_{2}=$ Not_Acceptable AND NO ${ }_{3}^{-}=$Not_Acceptable AND F ${ }^{-}=$Desirable & THEN WQ = Not_Acceptable \\
\hline $\mathrm{R}_{9}$ & $\mathrm{IF} \mathrm{G}_{1}=$ Acceptable AND G $2=$ Not_Acceptable AND NO ${ }_{3}{ }^{-}=$Desirable AND F $=$Not_Acceptable & THEN WQ = Not_Acceptable \\
\hline $\mathrm{R}_{10}$ & $\mathrm{IF} \mathrm{G}_{1}=$ Not_Acceptable AND G ${ }_{2}=$ Not_Acceptable AND NO ${ }^{-}=$Desirable AND F ${ }^{-}=$Desirable & THEN WQ = Not_Acceptable \\
\hline
\end{tabular}


For construction of the fuzzy model, a total number of 351 rules were developed on the basis of available datasets and experts' perception. In this model, the number of rules depends on the number of input parameters and membership functions. If we take the number of each parameter membership function as $\mu(\mathrm{x})$ and the number of input parameters as $\mathrm{n}$, then we can determine the number of rules $\mathrm{R}$ as $[24 ; 27]$ :

$$
R(\text { Rule })=\mu\left(x_{1}\right) \mu\left(x_{2}\right) \ldots \mu\left(x_{n}\right)
$$

Therefore, since the first group consists of 4 input parameters and each parameter consists of 3 membership functions, the implemented rules for this group equal 81 $(3 \times 3 \times 3 \times 3)$. In the same way, the implemented rules for each of the second and third groups equal $135(5 \times 3 \times 3 \times 3)$. Table 3 shows some of the applied rules for each group.

The proposed fuzzy model based on Mamdani implication of Max-Min operator was applied (Fig 5). In max-min operator, the minimum value from each rule is taken and stored in a group using fuzzy min operator and then by choosing the maximum value from that group gives the belongingness of that water sample quality to the specific category [2]
The results of the rules were combined and defuzzified via center of gravity method. On this basis, 60 groundwater samples were assessed. Table 4 presents the obtained data. The importance of FIS method is highlighted in the samples whose parameters values are placed in the definite limit borders. Taking into account the definite limit borders, Uncertainties play a pivotal role in the decision making procedure and sometimes result into making wrong decisions. The comparison of FIS decision making model and deterministic decision making is presented in table 4. On this basis, chemical quality of water samples No. 1 and 35, having a certainty level of $100 \%$, are reported as desirable; next in the ranking, water samples No. 5, 31 and 57, having a certainty level of $89.43 \%$, are reported as desirable for potable usages. In water sample No.29 with a deterministic method, three parameters of TA, $\mathrm{PH}$ and $\mathrm{F}^{-}$were at a desirable level, while four parameters of $\mathrm{NO}_{3}^{-}, \mathrm{Cl}^{-}, \mathrm{Mg}^{2+}$ and $\mathrm{Ca}^{2+}$ Were in acceptable group and three parameters of TDS, TH and $\mathrm{SO}_{4}{ }^{2-}$ were in not-acceptable group. This kind of decision making on the potable water quality is dubious for experts especially when human beings are taken into account.

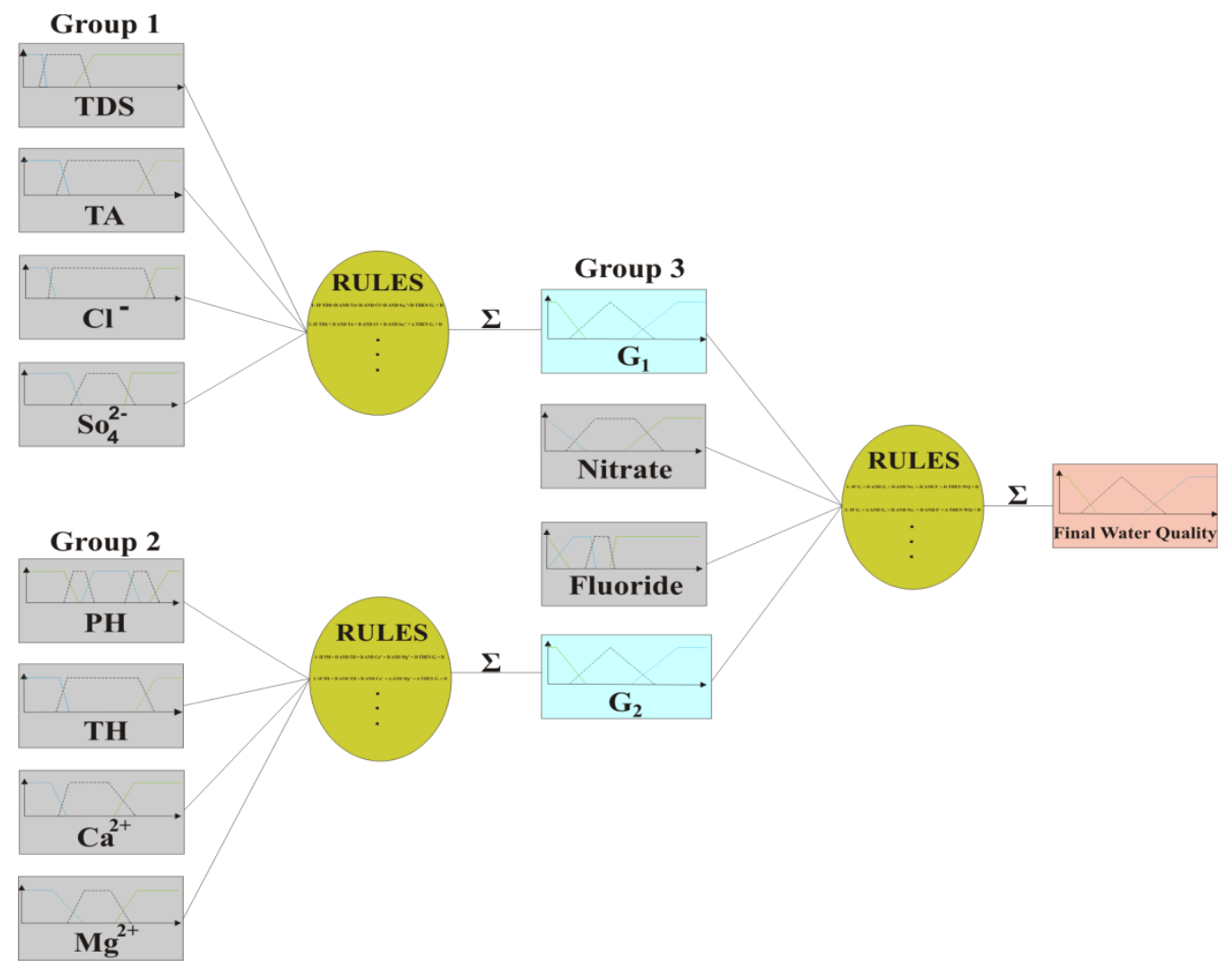

Fig 5: The schematic illustration of the fuzzy model

The distinction in the decision level between the MFIS method and deterministic method is clearly showed in the samples No. 2 and 7 and 55. In three samples with the deterministic method, three parameters of $\mathrm{PH}, \mathrm{F}^{-}$and $\mathrm{Mg}^{2+}$ were at a desirable level, five parameters of $\mathrm{TH}, \mathrm{TA}, \mathrm{Cl}^{-}, \mathrm{NO}_{3}^{-}$ and $\mathrm{Ca}^{2+}$ were in acceptable range and two parameters of TDS and $\mathrm{SO}_{4}{ }^{2-}$ were in not-acceptable group (Table 4). While, the decision has been taken with MFIS method for these two samples is entirely different. As the samples No. 7 and 55 with certainty levels of $36.86 \%$ and $59.14 \%$ respectively are at a desirable category, the sample No. 2 with certainty level of $43.33 \%$ is at a not-acceptable class. This distinction is related to the parameters with concentration greater than the desirable and admissible limits in each sample. In sample No. 7 and 55, the concentrations of acceptable and not-acceptable parameters are marginally higher than the desirable and admissible limits and stand in the domain of desirable and acceptable and acceptable and not-acceptable fuzzy membership functions, respectively. But, in sample No. 2 the concentration of acceptable and not-acceptable parameters are very high and lie in the range of acceptable and not-acceptable fuzzy membership function and not-acceptable fuzzy membership function respectively, and causes the water sample to be at not-acceptable class. In another case, all 
parameters of samples No. 1, 9, 12, 24, 25, 26, 27, 34, 35, 40 and 53 are in desirable level according to the deterministic method (Table 4). But in MFIS method, the samples No. 1, 9, 35,40 and 53 with certainty levels of $100 \%, 78 \%, 100 \%$, $42.57 \%$ and $71.59 \%$ respectively, belong to a desirable category, the samples No. 12, 24, 27 and 34 with certainty levels of $48 \%, 70.1 \%, 90 \%$ and $90 \%$ respectively, possessed by acceptable level, and the samples No. 25 and 26 with certainty levels of $82.22 \%$ and $81.67 \%$ respectively, were in not-acceptable group. In addition to the abovementioned reason, the main reason of distinction in these samples especially No. 25 and 26 are related to the definite Fluoride membership function. Fluoride concentration is less than 0.2 $\mathrm{mg} / \mathrm{l}$ in samples No. 25 and 26. Moreover, according to plotted fuzzy membership function on the basis of prescribed limits and expert perception, these amounts stand in the domain of not-acceptable fuzzy membership functions, whereas in other samples, Fluoride concentrations belong to acceptable and desirable classes. Therefore, the MFIS method plays an important role in the decision making process for evaluating the potability of groundwater in which both prescribed limits of various organizations and expert opinion will be considered.

Table 4. Detail on groundwater quality for drinking purposes by using FSE method and deterministic method (as per WHO standards)

\begin{tabular}{|c|c|c|c|c|}
\hline \multirow{2}{*}{ TW (no.) } & \multirow{2}{*}{$\begin{array}{c}\begin{array}{c}\text { Decision using MFIS } \\
\text { method }\end{array} \\
\end{array}$} & \multicolumn{3}{|c|}{ Decision using deterministic method } \\
\hline & & $\begin{array}{c}\text { Desirable } \\
\end{array}$ & Acceptable & Not-Acceptable \\
\hline 1 & Desirable(100) & TDS, TA, Cl, SO4, PH, TH, Ca, Mg, NO3, F & - & - \\
\hline 2 & Not-acceptable(43.3) & $\mathrm{PH}, \mathrm{F}, \mathrm{Mg}$ & $\mathrm{TH}, \mathrm{TA}, \mathrm{Cl}, \mathrm{Ca}, \mathrm{NO} 3$ & TDS, SO4 \\
\hline 3 & Acceptable $(90)$ & $\mathrm{TA}, \mathrm{Cl}, \mathrm{F}$ & TDS, SO4, PH, TH, Ca, Mg, NO3 & - \\
\hline 4 & Acceptable $(90)$ & TA, F & TDS, $\mathrm{Cl}, \mathrm{SO} 4, \mathrm{PH}, \mathrm{Ca}, \mathrm{Mg}, \mathrm{NO} 3$ & TH \\
\hline 5 & Desirable(89.43) & TA, SO4, PH, Ca, Mg & $\mathrm{TDS}, \mathrm{Cl}, \mathrm{TH}, \mathrm{NO} 3, \mathrm{~F}$ & - \\
\hline 6 & Not-acceptable(88.78) & PH & $\mathrm{TA}, \mathrm{Cl}$ & TDS, TH, F, SO4, NO3, Ca, Mg \\
\hline 7 & Desirable(36.86) & $\mathrm{PH}, \mathrm{Mg}, \mathrm{F}$ & $\mathrm{TH}, \mathrm{TA}, \mathrm{Cl}, \mathrm{Ca}, \mathrm{NO} 3$ & TDS, SO4 \\
\hline 8 & Not-acceptable(85.17) & $\mathrm{SO} 4, \mathrm{NO} 3$ & $\mathrm{PH}, \mathrm{TA}$ & TDS, TH, F, Cl, Ca, Mg \\
\hline 9 & Desirable(78) & TDS, TA, Cl, SO4, PH, TH, Ca, Mg, NO3, F & - & - \\
\hline 10 & Not-acceptable(82.22) & $\mathrm{SO} 4, \mathrm{PH}, \mathrm{Mg}, \mathrm{NO} 3$ & TA, TH, Ca & TDS, Cl, F \\
\hline 11 & Acceptable $(78)$ & TDS, TA, Cl, SO4, PH, Mg, NO3, F & $\mathrm{TH}, \mathrm{Ca}$ & - \\
\hline 12 & Acceptable(48) & TDS, TA, $\mathrm{Cl}, \mathrm{SO} 4, \mathrm{PH}, \mathrm{TH}, \mathrm{Ca}, \mathrm{Mg}, \mathrm{NO} 3, \mathrm{~F}$ & - & - \\
\hline 13 & Not-acceptable(85.5) & SO4, PH, NO3 & $\mathrm{TA}, \mathrm{Cl}, \mathrm{Ca}, \mathrm{Mg}$ & TDS, F \\
\hline 14 & Acceptable(73.74) & $\mathrm{TA}, \mathrm{PH}, \mathrm{Mg}, \mathrm{NO} 3, \mathrm{~F}$ & $\mathrm{Cl}, \mathrm{TH}, \mathrm{Ca}$ & TDS, SO4 \\
\hline 15 & Not-acceptable(86.22) & $\mathrm{Cl}, \mathrm{SO} 4, \mathrm{PH}$ & $\mathrm{TA}, \mathrm{Ca}, \mathrm{Mg}, \mathrm{NO} 3$ & TDS, TH, F \\
\hline 16 & Acceptable(82.4) & TDS, TA,F & $\mathrm{Cl}, \mathrm{SO} 4, \mathrm{PH}, \mathrm{Ca}, \mathrm{Mg}, \mathrm{NO} 3$ & TH \\
\hline 17 & Not-acceptable(76.67) & TA, Cl, SO4, PH, NO3 & $\mathrm{Ca}, \mathrm{Mg}$ & TDS, TH, F \\
\hline 18 & Desirable(39.71) & TDS, Cl, SO4, TH, Ca, Mg, NO3, F & TA & $\mathrm{PH}$ \\
\hline 19 & Not-acceptable(76.11) & $\mathrm{Cl}, \mathrm{SO} 4, \mathrm{PH}, \mathrm{NO} 3$ & TDS, TA, Ca, Mg & TH, F \\
\hline 20 & Acceptable $(90)$ & TDS, TA, Cl, SO4, PH, TH, Ca, NO3, F & $\mathrm{Mg}$ & \\
\hline 21 & Not-acceptable(84.83) & $\mathrm{SO} 4, \mathrm{PH}, \mathrm{NO} 3$ & $\mathrm{TA}, \mathrm{Cl}$ & TDS, TH, Ca, Mg, F \\
\hline 22 & Desirable(69.14) & $\mathrm{TA}, \mathrm{Cl}, \mathrm{SO} 4, \mathrm{PH}, \mathrm{TH}, \mathrm{Ca}, \mathrm{Mg}, \mathrm{F}$ & TDS, NO3 & - \\
\hline 23 & Acceptable(59.6) & $\mathrm{TA}, \mathrm{Cl}, \mathrm{PH}, \mathrm{Ca}, \mathrm{Mg}, \mathrm{NO} 3, \mathrm{~F}$ & TDS, SO4, TH & - \\
\hline 24 & Acceptable $(70.1)$ & TDS, TA, Cl, SO4, PH, TH, Ca, Mg, NO3,F & - & - \\
\hline 25 & Not-acceptable $(82.22)$ & TDS, TA, Cl, SO4, PH, TH, Ca, Mg, NO3, F & - & - \\
\hline 26 & Not-acceptable(81.67) & TDS, TA, Cl, SO4, PH, TH, Ca, Mg, NO3, F & - & - \\
\hline 27 & Acceptable(90) & TDS, TA, $\mathrm{Cl}, \mathrm{SO} 4, \mathrm{PH}, \mathrm{TH}, \mathrm{Ca}, \mathrm{Mg}, \mathrm{NO} 3, \mathrm{~F}$ & - & - \\
\hline 28 & Acceptable(37.07) & $\mathrm{TDS}, \mathrm{Cl}, \mathrm{SO} 4, \mathrm{PH}, \mathrm{NO} 3, \mathrm{~F}$ & TA, TH, Ca, Mg & - \\
\hline 29 & Acceptable $(82)$ & TA, PH, F & $\mathrm{Cl}, \mathrm{Ca}, \mathrm{Mg}, \mathrm{NO} 3$ & TDS, SO4, TH \\
\hline 30 & Not-acceptable $(88.78)$ & $\mathrm{TA}, \mathrm{Cl}, \mathrm{SO} 4, \mathrm{PH}, \mathrm{TH}, \mathrm{Ca}, \mathrm{Mg}$ & TDS & $\mathrm{NO} 3$ \\
\hline 31 & Desirable(89.43) & $\mathrm{TA}, \mathrm{SO} 4, \mathrm{PH}, \mathrm{TH}, \mathrm{Ca}, \mathrm{Mg}$ & $\mathrm{Cl}, \mathrm{NO} 3, \mathrm{~F}$ & TDS \\
\hline 32 & Not-acceptable(81.11) & TA, PH, F & $\mathrm{Cl}, \mathrm{Ca}, \mathrm{NO} 3$ & TDS, SO4, TH, Mg \\
\hline 33 & Desirable $(86.57)$ & $\mathrm{Cl}, \mathrm{SO} 4, \mathrm{PH}, \mathrm{TH}, \mathrm{Ca}, \mathrm{Mg}$ & TDS, TA, NO3 & - \\
\hline 34 & Acceptable $(90)$ & TDS, TA, Cl, SO4, PH, TH, Ca, Mg, NO3, F & - & - \\
\hline 35 & Desirable(100) & TDS, TA, Cl, SO4, PH, TH, Ca, Mg, NO3, F & - & - \\
\hline 36 & Acceptable(90) & $\mathrm{PH}, \mathrm{F}$ & TDS, TA, Cl, SO4, TH, Ca, Mg, NO3 & \\
\hline 37 & Acceptable $(74)$ & TA, $\mathrm{Cl}, \mathrm{PH}, \mathrm{Mg}, \mathrm{NO} 3$ & TDS, TH, Ca, F & SO4 \\
\hline 38 & Not-acceptable(81.11) & TDS, Cl, SO4,PH, TH, Mg, F & $\mathrm{TA}, \mathrm{Ca}, \mathrm{NO} 3$ & \\
\hline 39 & Acceptable(78) & $\mathrm{SO} 4, \mathrm{PH}$ & $\mathrm{TA}, \mathrm{Cl}, \mathrm{Ca}, \mathrm{Mg}, \mathrm{NO} 3, \mathrm{~F}$ & TDS, TH \\
\hline 40 & Desirable(42.57) & TDS, TA, Cl, SO4, PH, TH, Ca, Mg, NO3, F & - & - \\
\hline 41 & Desirable(85.43) & $\mathrm{TA}, \mathrm{PH}, \mathrm{TH}, \mathrm{Ca}, \mathrm{Mg}, \mathrm{NO} 3, \mathrm{~F}$ & TDS, $\mathrm{Cl}, \mathrm{SO} 4$ & - \\
\hline 42 & Acceptable $(92)$ & $\mathrm{TA}, \mathrm{Cl}, \mathrm{SO} 4, \mathrm{PH}, \mathrm{TH}, \mathrm{Ca}, \mathrm{Mg}, \mathrm{NO} 3$ & TDS, F & - \\
\hline 43 & Not-acceptable(78.33) & $\mathrm{SO} 4, \mathrm{PH}, \mathrm{NO} 3, \mathrm{~F}$ & $\mathrm{TA}, \mathrm{Cl}, \mathrm{TH}, \mathrm{Ca}, \mathrm{Mg}$ & TDS \\
\hline 44 & Desirable(59.43) & $\mathrm{TA}, \mathrm{SO} 4, \mathrm{PH}, \mathrm{Mg}, \mathrm{NO} 3, \mathrm{~F}$ & TDS, $\mathrm{Cl}, \mathrm{TH}, \mathrm{Ca}$ & - \\
\hline 45 & Desirable(52.28) & $\mathrm{Cl}, \mathrm{SO} 4, \mathrm{PH}, \mathrm{Mg}, \mathrm{NO} 3, \mathrm{~F}$ & TDA, TA, TH, Ca & - \\
\hline 46 & Acceptable $(90)$ & $\mathrm{Cl}, \mathrm{SO} 4, \mathrm{PH}, \mathrm{Mg}, \mathrm{NO} 3, \mathrm{~F}$ & TDS, TA, TH, Ca & - \\
\hline 47 & Not-acceptable $(80.56)$ & $\mathrm{TA}, \mathrm{Cl}, \mathrm{SO} 4, \mathrm{PH}, \mathrm{TH}, \mathrm{Ca}, \mathrm{Mg}, \mathrm{NO} 3, \mathrm{~F}$ & TDS & - \\
\hline 48 & Not-acceptable(78.89) & $\mathrm{TA}, \mathrm{Cl}, \mathrm{PH}, \mathrm{Mg}, \mathrm{NO} 3$ & TDS, SO4, TH, Ca & $\mathrm{F}$ \\
\hline 49 & Acceptable(53.3) & $\mathrm{Cl}, \mathrm{SO} 4, \mathrm{Mg}, \mathrm{NO} 3$ & TDS, PH, TH, Ca, F & TA \\
\hline 50 & Desirable(48.8) & $\mathrm{TA}, \mathrm{Cl}, \mathrm{SO} 4, \mathrm{PH}, \mathrm{Ca}, \mathrm{Mg}, \mathrm{NO} 3, \mathrm{~F}$ & TDS, TH & - \\
\hline 51 & Desirable(89.42) & $\mathrm{SO} 4, \mathrm{PH}, \mathrm{Mg}, \mathrm{F}$ & TDS, TA, $\mathrm{Cl}, \mathrm{TH}, \mathrm{Ca}, \mathrm{NO} 3$ & - \\
\hline 52 & Not-acceptable(78.77) & $\mathrm{SO} 4, \mathrm{NO} 3$ & $\mathrm{TA}, \mathrm{Cl}, \mathrm{PH}$ & TDS, TH, Ca, Mg, F \\
\hline 53 & Desirable(71.59) & TDS, TA, Cl, SO4, PH, TH, Ca, Mg, NO3, F & - & - \\
\hline 54 & Acceptable(69.9) & $\mathrm{Cl}, \mathrm{SO} 4, \mathrm{PH}, \mathrm{Mg}, \mathrm{NO} 3, \mathrm{~F}$ & TDS, TA, TH, Ca & - \\
\hline 55 & Desirable(59.14) & $\mathrm{PH}, \mathrm{Mg}, \mathrm{F}$ & $\mathrm{TH}, \mathrm{TA}, \mathrm{Cl}, \mathrm{Ca}, \mathrm{NO} 3$ & TDS, SO4 \\
\hline 56 & Not-acceptable(85.5) & $\mathrm{SO} 4, \mathrm{PH}, \mathrm{Mg}, \mathrm{NO} 3$ & TDS, TA, Cl, TH, Ca & $\mathrm{F}$ \\
\hline 57 & Desirable(89.43) & $\mathrm{TA}, \mathrm{Cl}, \mathrm{SO} 4, \mathrm{PH}, \mathrm{TH}, \mathrm{Ca}, \mathrm{Mg}, \mathrm{F}$ & TDS, $\mathrm{NO} 3$ & - \\
\hline 58 & Desirable(32.29) & $\mathrm{TA}, \mathrm{PH}, \mathrm{Mg}, \mathrm{NO} 3$ & TDS, Cl, SO4, TH, Ca, F & - \\
\hline 59 & Desirable $(85.71)$ & $\mathrm{SO} 4, \mathrm{PH}, \mathrm{Mg}, \mathrm{NO} 3, \mathrm{~F}$ & TDS, TA, Cl, TH, Ca & - \\
\hline 60 & Not-acceptable(88.78) & $\mathrm{PH}$ & TDS, TA, Cl & $\mathrm{TH}, \mathrm{F}, \mathrm{SO} 4, \mathrm{NO} 3, \mathrm{Ca}, \mathrm{Mg}$ \\
\hline
\end{tabular}




\section{CONCLUSION}

In this research, applicability of MFIS method for groundwater quality to potable purpose was investigated in comparison with deterministic methods. In deterministic method, the quality of each parameter on the basis of prescribed limits in drinking water standards (in this case WHO and ISIRI) categorized in three form of desirable, acceptable and not-acceptable. It is difficult and obscure to make a decision about of groundwater quality using deterministic methods. In MFIS evaluation method, not only the potable water quality is classified as the three forms, but also can easily suggest about final groundwater quality. Moreover, we can specify the confidence level (or certainty level) to each form. In this study, among 60 groundwater samples, 20 samples (with certainty level of 32.29-100\%) were classified in desirable class for drinking, 20 samples (with certainty level of $37.07-92 \%$ ) were in acceptable category and 20 samples (with certainty level of 43.33$88.78 \%$ ) were in not-acceptable group.

\section{REFERENCES}

[1] Bai, R.V., Bouwmeester, R. and Mohan, S. 2009. Fuzzy logic Water Quality index and importance of Water Quality Parameters. Air, Soil and Water Research. 2, 5159.

[2] Dahiya, S., Singh, B., Gaur, S., Garg, V.K. and Kushwaha, H.S. 2007. Analysis of groundwater quality using fuzzy synthetic evaluation. Journal of Hazardous Materials. 147, 938-946.

[3] Venkat Kumar, N., Mathew, S. and Swaminathan, G. 2009. Fuzzy Information Processing for Assessment of Groundwater Quality. International journal of soft Computing. 4 (1), 1-9.

[4] Yin, J. and Wu, Z. 2008. Fuzzy Synthetic Evaluation of Water Quality with Membership Functions Constructed by Linear Interpolation. Fifth International Conference on Fuzzy Systems and Knowledge Discovery.

[5] Singh, P.K., Basant, A., Malik, A. and Jain, G. 2009. Artificial neural network modeling of the river water quality-A case study. Ecological Modelling. 220, 888895.

[6] Yi-Ming, K., Chen-Wuing, L. and Kao-Hung, L. 2004. Evaluation of the ability of an artificial neural network model to assess the variation of groundwater quality in an area of blackfoot disease in Taiwan.Water Research. $38,148-158$.

[7] Mahapatra, S.S., Nanda, S.K. and Panigrahy, B.K. 2011. A Cascaded Fuzzy Inference System for Indian river water quality prediction. Advances in Engineering Software. 42, 787-796.

[8] Ocampo-Duque, W., Ferre-Huguet, N., Domingo, J.L. and Schuhmacher, M. 2006. Assessing water quality in rivers with fuzzy inference systems: A case study. Environment International. 32, 733-742.

[9] Ip, W.C., Hu, B.Q., Wong, H. and Xia, J. 2009. Applications of grey relational method to river environment quality evaluation in China. Journal of Hydrology. 379, 284-290.

[10] Simoes, F.D.S., Moreira, A.B., Bisinoti, M.C., Gimenez, S.M.N. and Yabe, M.J.S. 2008. Water Quality Index as a
Simple Indicator of Aquaculture Effects on Aquatic Bodies. Ecological Indicators. 8, 476-484.

[11] Srebotnjak, T., Carr, G., De Sherbinin, A. and Rickwood, C. 2011. A global Water Quality Index and hot-deck imputation of missing data. Ecological Indicators. Article in press.

[12] De Rosemond, S., Duro, D.C. and Dube, M. 2009. Comparative analysis of regional water quality in Canada using the Water Quality Index. Environmental Monitoring and Assessment. 156, 223-240.

[13] Fulazzaky, M.A. 2010. Water quality evaluation system to assess the status and the suitability of the Citarum river water to different uses. Environmental Monitoring and Assessment, 168, 669-684.

[14] Chang, N.B., Chen, H.W. and Ning, S.K. 2001. Identification of river water quality using the Fuzzy Synthetic Evaluation approach. Journal of Environmental Management. 63, 293-305.

[15] Icaga, Y. 2007. Fuzzy evaluation of water quality classification. Ecological Indicators. 7, 710-718.

[16] Lermontov, A., Yokoyama, L., Lermontov, M. and Augusta Soares Machado, M. 2009. River quality analysis using fuzzy water quality index: Ribeira do Iguape river watershed, Brazil. Ecological Indicators. 9, 1188-1197.

[17] Sii, H.I., Sherrard, J.H. and Wilson, T.E. 1993. Development of a water quality index based on fuzzy set theory and intended water use. Proc. Joint ASCE-CSCE National Conference on Environmental Engineering. July 12-14, Montreal, Quebec, Canada, 253-259.

[18] Garg, V.K., Dahiya, S., Chaudhary, A. and Deepshikha, A. 1998. Fluoride distribution in underground waters of Jind district, Haryana, India. Ecology Environmental Conservation. 40, 19-23.

[19] Genther, H. and Glesner, M. 1997. Advanced data preprocessing using fuzzy clustering techniques. Fuzzy Sets and Systems. 85,155-164.

[20] Delgado, M., Gomez-Skarmeta, A. F. and Martin, F. 1998. A methodology to model fuzzy systems using fuzzy clustering in a rapid-prototyping approach. Fuzzy Sets and Systems. 97, 287-301.

[21] Ishibuchi, H., Nakashima, T. and Morisawa, T. 1999. Voting fuzzy rule-based systems for pattern classification. Fuzzy Sets and Systems. 103, 223-238.

[22] Rahmanian, B., Pakizeh, M., Esfandyari, M., Heshmatnezhad, F. and Maskooki, A. 2011. Fuzzy modeling and simulation for lead removal using micellar-enhanced ultrafiltration (MEUF). Journal of Hazardous Materials. 192, 585- 592.

[23] Jacquin, A.P. and Shamseldin, A.Y. 2008. Development of Rainfall-Runoff Models Using Mammdani-Type Fuzzy Inference Systems. Water Science and Technology Library. 1, practical Hydroinformatics. 68(3), 189-200.

[24] Firat, M., ErkanTuran, M. and Yurdusev, M.A. 2009. Comparative analysis of fuzzy inference systems for water consumption time series prediction. Journal of Hydrology. 374,235-241. 
[25] Kadkhodaie, A., Rezaee, M.R., Rahimpour-Bonab, H., Chehrazi, A. 2009. Petrophysical data prediction from seismic attributes using committee fuzzy inference system. Computers \& Geosciences. 35, 2314-2330.

[26] Akgun, A., Sezer, E.A., Nefeslioglu, H.A., Gokceoglu, C. and Pradhan, B. 2011. An easy-to-use MATLAB program (MamLand) for the assessment of landslide susceptibility using a Mamdani fuzzy algorithm. Computers \& Geosciences. Article in press.

[27] Sen, Z. and Altunkaynak, A. 2009. Fuzzy system modeling of drinking water consumption prediction. Expert Systems with Applications. 36, 11745-11752.

[28] Yel, E. and Yalpir, S. 2011. Prediction of primary treatment effluent parameters by Fuzzy Inference System (FIS) approach. Procedia Computer Science. 3, 659-665.

[29] Zadeh, L.A. 1965. Fuzzy set. Information Control. 8(3), 338-353.

[30] Monjezi, M. and Rezaei, M. 2011. Developing a new fuzzy model to predict burden from rock geomechanical properties. Expert Systems with Applications. 38, 92669273.

[31] Sadiq, R., Husain, T., Veitch, B. and Bose, N. 2004. Risk-based decision-making for drilling waste discharges using a fuzzy synthetic evaluation technique. Ocean Engineering, 31, 1929-1953.

[32] Li, Z., Halang, W.A. and Chen, G. 2006. Integration of Fuzzy Logic and Chaos Theory. Springer Berlin Heidelberg New York.

[33] Katambara, Z. and Ndiritu, J., 2009. A fuzzy inference system for modeling stream flow: Case of Letaba River, South Africa. Physics and Chemistry of the Earth. 34, 688-700.

[34] Hu, Z.Y., Huang, G.H., Chan, C.W. 2003. A fuzzy process controller for in situ groundwater bioremediation. Engineering Applications of Artificial Intelligence. 16, 131-147.

[35] Monjezi, M., Rezaei, M. and YazdianVarjani, A. 2009. Prediction of rock fragmentation due to blasting in GolE-Gohar iron mine using fuzzy logic. International Journal of Rock Mechanics and Mining Sciences. 46, $1273-1280$

[36] Bakhtyar, R., Ghaheri, A., Yeganeh-Bakhtiary, A. and Jeng, D.S. 2011. Cross-shore sediment transport estimation using fuzzy inference system in the swash zone. Journal of the Franklin Institute. 348, 2005-2025.

[37] Mamdani, E.H. and Assilian, S. 1975. An experimental in linguistic synthesis with a fuzzy logic control. International Journal of Man-Machine Studies, 7, 1-13.

[38] Takagi, T. and Sugeno, M. 1985. Fuzzy identification of systems and its application to modeling and control.
IEEE Transactions on Systems, Man and Cybernetics. $15,116-132$

[39] Tosun, M., Dincer, K. and Baskaya, S. 2011. Rule-based Mamdani-type fuzzy modeling of thermal performance of multi-layer precast concrete panels used in residential buildings in Turkey. Expert Systems with Applications. $38,5553-5560$.

[40] Keshwani, D.R., Jones, D.D., Meyer, G.E. and Brand, R.M. 2008. Rule-based Mamdani-type fuzzy modeling of skin permeability. Applied Soft Computing. 8, 285-294.

[41] Solangi, I.B., Memon, S. and Bhanger, M.I. 2009. Removal of fluoride from aqueous environment by modified Amberlite resin. Journal of Hazardous Materials. 171, 815-819.

[42] Dinga, Y., YanhuiGaoa.,Suna, H., Hepeng, Hana, Wanga, W., Jia, X., Liub, X. and Suna, D. 2011. The relationships between low levels of urine fluoride on children's intelligence, dental fluorosis in endemic fluorosis areas in Hulunbuir, Inner Mongolia, China. Journal of Hazardous Materials. 186, 1942-1946.

[43] Harrison, P.T.C. 2005. Fluoride in water: a UK perspective. Journal of Fluorine Chemistry. 126, 14481456.

[44] Liu, M. and Qian, C. 2008. Effect of endemic fluorosis on children's intelligence development: a meta analysis, Chin. Journal of Contemporary Pediatrics, 10, 723-725.

[45] Meenakshi, Garg, V.K., Kavita, Renuka and Malik, A. 2004. Groundwater quality in some villages of Haryana, India: focus on fluoride and fluorosis. Journal of Hazardous Materials. 106B, 85-97.

[46] Mohapatra, M., Anand, S., Mishra, B.K., Giles, D.E. and Singh, P. 2009. Review of fluoride removal from drinking water. Journal of Environmental Management. 91, 67-77.

[47] Zhaoa, X., Fenga, C., Wang, Q., Yang, Y., Zhang, Z. and Sugiura, N. 2011. Nitrate removal from groundwater by cooperating heterotrophic with autotrophic denitrification in a biofilm-electrode reactor. Journal of Hazardous Materials. 192(3), 1033-1039.

[48] Erkekoglu, P. and Baydar, T. 2010. Nitrite, a Hidden Foe in Foods: Evaluation of Nitrite in Toxicological Perspective. Gazi University Journal of Science. 23(3), 261-270.

[49] World Health Organization (WHO). 2006. "Guidelines for Drinking Water Quality", incorporating first addendum, Vol.1, Recommendations. - 3rd ed.

[50] Institute of Standards and Industrial Research of Iran (ISIRI), 1998. Characteristics of drinking water. Standard No.1053. 